\title{
Potential utilization of bagasse as feed material for earthworm Eisenia fetida and production of vermicompost
}

\author{
Sartaj Ahmad Bhat ${ }^{1}$, Jaswinder Singh ${ }^{2}$ and Adarsh Pal Vig ${ }^{1 *}$
}

\begin{abstract}
In the present work bagasse (B) i.e waste of the sugar industry, was fed to Eisenia fetida with cattle dung (CD) support as feed material at various ratios (waste: $C D)$ of 0:100 $\left(B_{0}\right), 25: 75\left(B_{25}\right), 50: 50\left(B_{50}\right), 75: 25\left(B_{75}\right)$ and 100:0 $\left(B_{100}\right)$ on dry weight basis. Co-composting with cattle dung helped to improve their acceptability for E. fetida and also improved physico-chemical characteristics. Best appropriate ratio for survival, maximum growth and population buildup of E. fetida was determined by observing population buildup, growth rate, biomass, mortality and cocoon formation. Minimum mortality and highest population size of worms was observed in 50:50 ( $\left.B_{50}\right)$ ratio. Increasing concentrations of wastes significantly affected the growth and reproduction of worms. Nutrients like nitrogen, phosphorus and sodium increased from pre-vermicompost to post-vermicompost, while organic carbon, and C:N ratio decreased in all the end products of post-vermicomposting. Heavy metals decreased significantly from initial except zinc, iron and manganese which increased significantly. Scanning electron microscopy (SEM) was used to recognize the changes in texture in the pre and post-vermicomposted samples. The post-vermicomposted ratios in the presence of earthworms validate more surface changes that prove to be good manure. The results observed from the present study indicated that the earthworm E. fetida was able to change bagasse waste into nutrient-rich manure and thus play a major role in industrial waste management.
\end{abstract}

Keywords: Vermicomposting; Sugar mill waste; Bagasse waste; Eisenia fetida; Growth and population

\section{Introduction}

In Indian economy the sugar mill has an essential place and contributes considerably to its exports earnings. India is the second largest producer of sugar and its byproducts amongst the 83 sugarcane producing countries in the world (Rao 2005). The industry succeed a very impressive gain as it has 1062 sugar industries of large to medium size as compared to 138 during 1950-1951 (Sangwan et al. 2008). About 270 million tons of sugar cane per year is produced in India (Zeyer et al. 2004). During the manfacturing process large amount of byproducts such as bagasse, pressmud and sugar cane residue are produced. Bagasse (B) is the fibrous waste produced in the sugarcane juice extraction process. It constitutes cellulose (50\%), hemicelluloses (25\%) and lignin (25\%)

\footnotetext{
* Correspondence: dr.adarshpalvig@gmail.com

${ }^{1}$ Department of Botanical and Environmental Science, Guru Nanak Dev University, Amritsar, India

Full list of author information is available at the end of the article
}

(Ezhumalai and Thangavelu 2010). Bagasse is a highly homogeneous material constitute around $30-40 \%$ of pith fibre, which is obtained from the core of the plant. The estimated generation is $0.25-0.30$ ton per ton of sugarcane (Pessoa et al. 1997). In agro-residue based pulp and paper mills, bagasse is used as a raw material. Disposal of bagasse by dumping is unattractive process because of large requirement of land and pollution concerns. Vermicomposting is the good method of converting organic wastes into environmentally friendly products. It is a biooxidative process entails the combined action of earthworms and microbes. Earthworms ingest, break and digest waste and converts into finer, humified, microbially active material by the activity of earthworms and microbes (Khwairakpam and Bhargava 2009). The final product i.e. vermicompost is a granulated material with high porosity and water holding capacity.

In the present work, bagasse of sugar industry was subjected to vermicomposting for its bioremediation. 
Co-composting with cattle dung helped to improve their acceptability for Eisenia fetida and also improved physico-chemical characteristics. Growth and fecundity of $E$. fetida were taken as parameters of appropriate feed ratios. Efficiency of $E$. fetida for recuperate nutrients was analysed by physico-chemical parameters in the waste and vermicompost after bioconversion. Scanning electron microscopy (SEM) was applied to recognize the changes in surface morphology in the pre and postvermicomposted samples.

\section{Materials and methods}

\section{Bagasse, Cattle dung and Eisenia fetida}

Fresh B was obtained from Rana Sugars Limited, Amritsar, Punjab, India. CD was obtained from a dairy farm situated in the vicinity of the university. Young non-clitellated $E$. fetida with an average weight $0.05 \mathrm{~g}$ were randomly picked from a stock culture maintained in the vermicomposting unit of the Department of Botanical and Environmental Sciences, Guru Nanak Dev University, Amritsar, Punjab, India. The initial physico-chemical parameters of $\mathrm{B}$ and $\mathrm{CD}$ are given in Table 1.

\section{Experimental setup}

$B$ and $C D$ were mixed and subjected to vermicomposting in the concentrations of 0:100 $\left(\mathrm{B}_{0}\right), 25: 75\left(\mathrm{~B}_{25}\right), 50: 50$ $\left(\mathrm{B}_{50}\right), 75: 25\left(\mathrm{~B}_{75}\right)$ and 100:0 $\left(\mathrm{B}_{100}\right)$ (waste: $\mathrm{CD}$ ) on a dry weight basis (Table 2). The experiments were run in plastic trays $(28 \times 3 \times 6 \mathrm{~cm})$ in triplicates under the vermicomposting unit of the university. The total weight of each tray was kept at $2 \mathrm{~kg}$. The trays were covered with hessian cloth and mixtures were turned over manually every 24 hours for 14 days in order to remove volatile toxic gases. After 14 days, 50 young non-clitellated $E$.

Table 1 Initial physico-chemical properties of bagasse and cattle dung

\begin{tabular}{lll}
\hline Physico-chemical parameters & Bagasse & Cattle dung \\
\hline $\mathrm{pH}$ & $6.55 \pm 0.07$ & $8.35 \pm 0.08$ \\
$\mathrm{EC}(\mathrm{mS} / \mathrm{cm})$ & $1.1 \pm 0.1$ & $4.13 \pm 0.17$ \\
$\mathrm{TKN}(\%)$ & $0.26 \pm 0.01$ & $1.34 \pm 0.01$ \\
$\mathrm{TOC}(\%)$ & $55.53 \pm 0.27$ & $46.28 \pm 0.52$ \\
$\mathrm{C}: \mathrm{N}$ ratio & $213.57 \pm 10.6$ & $34.53 \pm 0.26$ \\
$\mathrm{TAP}(\%)$ & $0.20 \pm 0.05$ & $0.59 \pm 0.06$ \\
$\mathrm{TK}(\%)$ & $3.19 \pm 0.04$ & $2.23 \pm 0.04$ \\
$\mathrm{TNa}(\%)$ & $1.08 \pm 0.10$ & $8.09 \pm 0.28$ \\
$\mathrm{Zn}{ }^{\mathrm{a}}$ & $21.54 \pm 0.24$ & $63.52 \pm 1.62$ \\
$\mathrm{Cu}$ & $18.6 \pm 1.41$ & $55.57 \pm 3.73$ \\
$\mathrm{Cr}^{\mathrm{a}}$ & $26.03 \pm 2.64$ & $56.77 \pm 4.28$ \\
$\mathrm{Fe}^{\mathrm{a}}$ & $249.5 \pm 7.67$ & $1483 \pm 6.44$ \\
$\mathrm{Mn}^{\mathrm{a}}$ & $16.79 \pm 1.72$ & $83.09 \pm 0.38$ \\
\hline
\end{tabular}

${ }^{\mathrm{a}}$ Weight in $\mathrm{mg} / \mathrm{Kg}$.
Table 2 Percentages of bagasse and cattle dung in different proportions on dry weight basis

\begin{tabular}{lll}
\hline Feed mixtures & Bagasse (B) & Cattle dung (CD) \\
\hline$B_{0}$ & 0 & 100 \\
$B_{25}$ & 25 & 75 \\
$B_{50}$ & 50 & 50 \\
$B_{75}$ & 75 & 25 \\
$B_{100}$ & 100 & 0 \\
\hline
\end{tabular}

fetida were added to the feed mixtures. The moisture content was maintained to $60-70 \%$ throughout the experiment by watered regularly. Earthworms, cocoons and hatchlings were sorted and counted manually at the interval of 15 days and then placed back in the trays after sampling. At the end of the experiment, worms, cocoons and hatchlings were taken out and put back in separate stock culture. The vermicompost was air dried, sieved and stored at low temperature i.e $10^{\circ} \mathrm{C}$ for physico-chemical analysis.

\section{Physico-chemical analysis}

$\mathrm{pH}$ and electrical conductivity (EC) of initial feed mixture and final products were measured in distilled water suspension of each concentration in the ratio of 1:10 (W/V) using Systronics $\mu \mathrm{pH}$ system 362 and Systronics conductivity meter-304, respectively. Total organic carbon (TOC) was determined after burning the $0.5 \mathrm{~g}$ of waste in a muffle furnace at $550^{\circ} \mathrm{C}$ for $60 \mathrm{~min}$ as described by Nelson and Sommers (1996). Micro-Kjeldhal method of AOAC (2000) was used for measuring nitrogen after digesting the waste in digestion mixture $\left(\mathrm{H}_{2} \mathrm{SO}_{4}+\mathrm{K}_{2} \mathrm{SO}_{4}: \mathrm{CuSO}_{4}: \mathrm{SeO}_{2}\right.$ in 10:4:1). The method described by John (1970) was used for measuring total available phosphorus (TAP) using Systronics double beam spectrophotometer 2202, total potassium (TK) and sodium (TNa) was measured by using a Systronics flame photometer- 128 after digesting the samples in diacid mixture $\left(\mathrm{HClO}_{4}: \mathrm{HNO}_{3}\right.$ in 4:1 ratio). Heavy metals were measured by Agilent 240 FS AA model Atomic Absorption Spectrophotometer in the digested samples.

\section{Scanning electron microscopy}

The pre and post-vermicomposted samples were analyzed to study the texture using Zeiss EVO LS-10 electron microscope. About 2-3 mg sample of particle size $300 \mathrm{~mm}$ was spread uniformly over the stub with the help of a double sided adhesive tape and subsequently coated with gold using sputter coater and imaged under SEM at different magnifications.

\section{Statistical analysis}

The differences among various feed mixtures were calculated by One-way ANOVA followed by Tukey's HSD 
test. Student's paired $t$-test was used to assess differences between pre and post-vermicompost values of various physico-chemical parameters. Experiment was run in triplicate and statistical analysis was done on triplicate values. Statistical analysis was done with the help of SPSS version 16.0 and Minitab version 14.0 computer software programs.

\section{Results and discussion}

\section{Increase in number and biomass of earthworm}

Population buildup in various mixtures of bagasse was significantly different $(\mathrm{p}<0.05)$. Earthworm number started increasing on 60th day in $\mathrm{B}_{0}, \mathrm{~B}_{25}$ and $\mathrm{B}_{50}$ mixtures and the increase continued till the 105th day of experiment. At the 105th day of experiment maximum increase was observed in $B_{50}(82 \pm 3.21)$ followed by $B_{25}$ $(78.33 \pm 2.96)$ and $B_{0}$ mixture $(76.67 \pm 2.33)$ (Figure 1$)$. The earthworm number decreased from 15th day of experiment in $\mathrm{B}_{100}$ mixture. In $\mathrm{B}_{75}$ mixture, however, a decline in numbers up to 60th day was followed by an increase up to 105th day. Only $46.33 \pm 3.93$ and $22.33 \pm 3.18$ worms were present on the 135th day in $B_{75}$ and $B_{100}$ feed mixtures. The maximum earthworm biomass was in the $\mathrm{B}_{50}$ $(79.04 \pm 2.60)$ feed mixture on the 105th day of experiment and minimum in the $B_{100}(15.83 \pm 1.93)$ feed mixture on the 135th day of experiment (Figure 2). Survival, biomass formation and reproduction of earthworms are the best sign to analyse the vermicomposting process. In the present study the number of worms in bagasse started to decrease between 105th and 135th days of experiment. At this time the vermicompost started granulating on the surface which demonstrates finishing of food in the mixtures. Continuous decline of earthworms was observed in the higher mixtures of bagasse $\left(B_{100}\right)$ till the end of the experiment, which hints towards its toxicity for earthworms even after 135 days. The survival, growth rate and reproduction potential of earthworms has been affected by the type, palatability and quality of food (Tripathi and Bhardwaj 2004; Gajalakshmi et al. 2005). Our results corroborate with the findings of Bhat et al. (2014) that an increasing content of pressmud in the feed mixture brought a decrease in the number of earthworms. Ideal ratio of bagasse with cattle dung was 50: 50, as final vermicompost started granulating on its surface earliest (90-100 days) and this ratio was also found to be suitable for growth and population buildup of E. fetida. In the present study also worm biomass increased in all feed mixtures of bagasse. Rathinamala et al. (2008) also reported increase in body weight of Eisenia eugeniae feeding on different organic substrates. Presence of fungi during vermicomposting processes becomes additional food to the worms which contributes to the higher weight of the worms (Pramanik and Chung 2011).

\section{Cocoon production}

The number of cocoons in different mixtures of bagasse was significantly different $(\mathrm{p}<0.05)$. Cocoon formation started after 30th day in $B_{0}, B_{25}, B_{50}$ and $B_{75}$ and after 75 th day in $B_{100}$. The maximum number of cocoons were observed in $B_{50}(214.7 \pm 4.91)$ on 105th day and minimum in $\mathrm{B}_{100}(22.33 \pm 4.05)$ on 135 th day (Figure 3$)$. Quality of the feed mixture determines the growth of

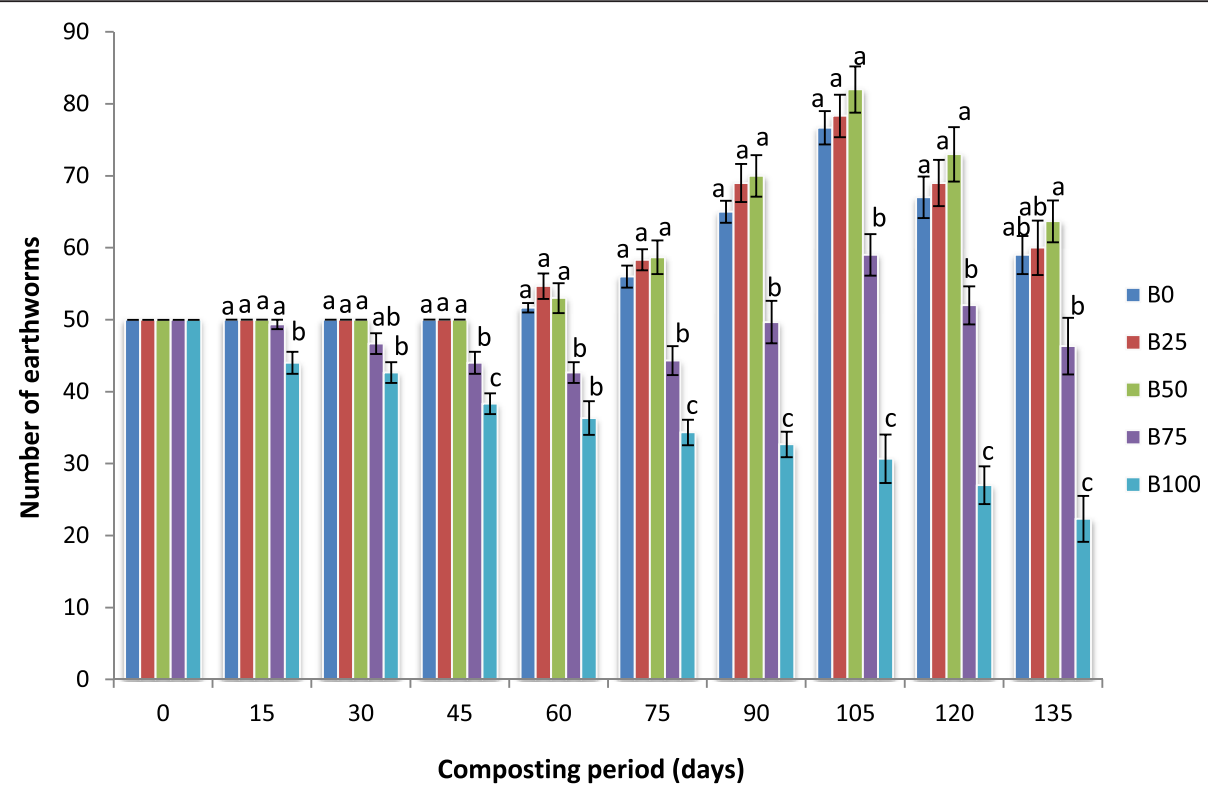

Figure 1 Mean values of number of earthworms followed by different letters in a same day are significantly different (one-way ANOVA; Tukey's test, $p \leq 0.05$ ) in different feed mixtures of bagasse and cattle dung. 


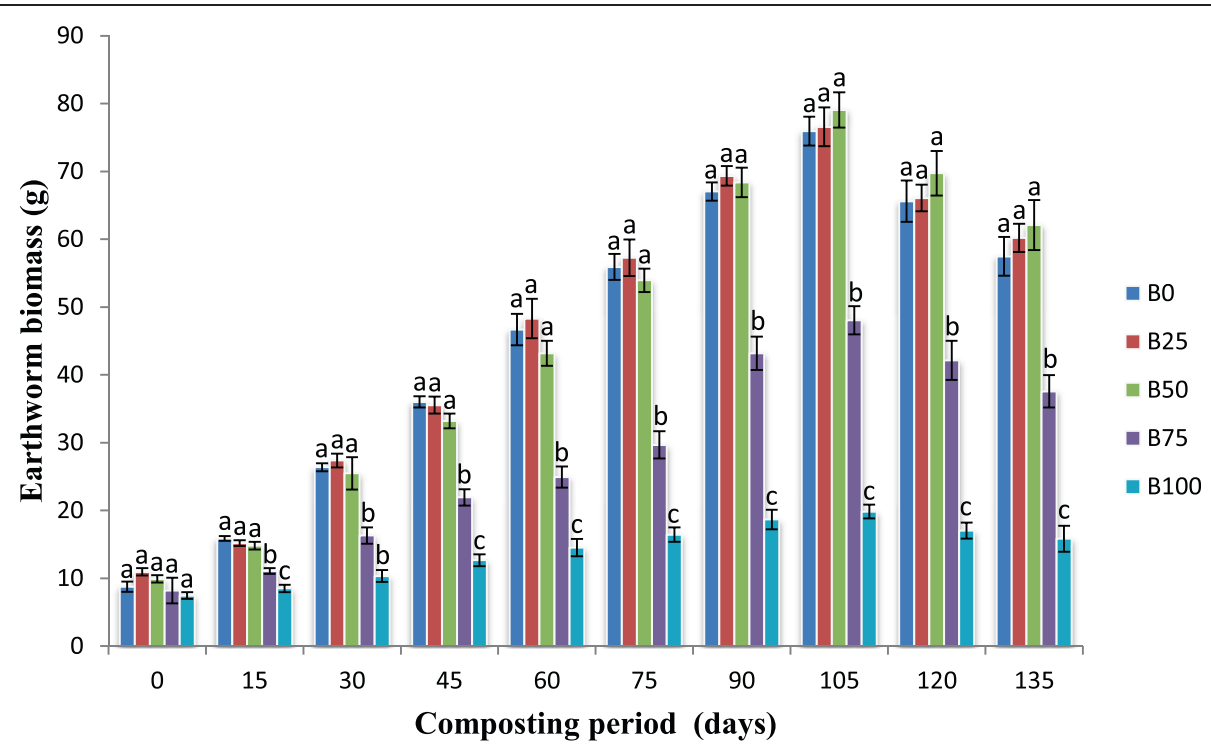

Figure 2 Mean values of earthworm biomass (g) followed by different letters in a same day are significantly different (one-way ANOVA; Tukey's test, $\mathrm{p} \leq 0.05$ ) in different feed mixtures of bagasse and cattle dung.

earthworms and onset as well as the rate of cocoon formation. Cocoon production was relatively less in higher concentrations $\left(B_{75}, B_{100}\right)$ as these mixtures contain less nitrogen content as contrast to the other feed mixtures, thus it could be reason for less cocoon production in this mixture. The results are also supported by the findings of Suthar (2007) that the nitrogen amount of the substrates as an important factor related to cocoon production. Fayolle et al. (1997) have also observed that food source play a crucial role on cocoon formation. Higher concentrations declined rate of degradation and drastically affected the earthworms as it delayed as well as decreased cocoon formation. Chauhan and Singh (2012) have also reported that the various binary combination of buffalo dung with agro-wastes caused a significant growth of E. fetida and increase in cocoons production.

\section{Hatchling formation and weight of hatchlings}

Hatchling formation was significantly different $(\mathrm{p}<0.05)$. Hatchlings were observed for the first time on 45th day in $B_{0}, B_{25}$ and $B_{50}$, on 60th day in $B_{75}$ and on 90th day in $B_{100}$ mixture. The maximum number of hatchlings were

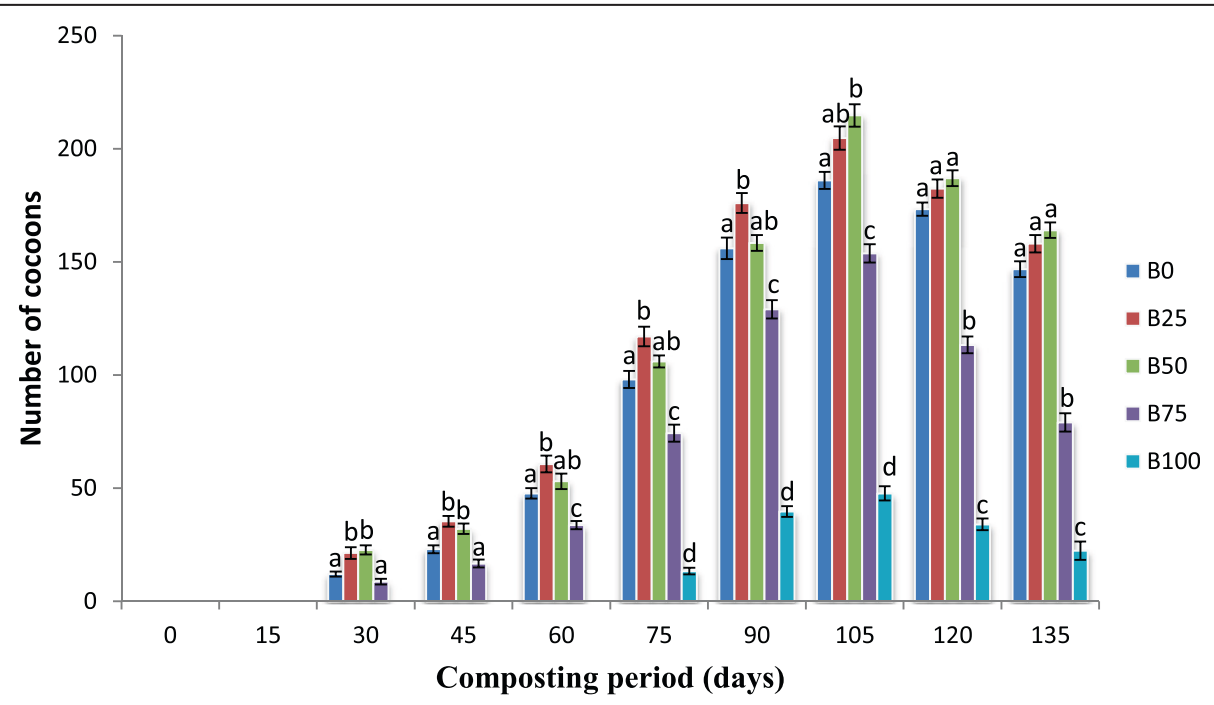

Figure 3 Mean values of number of cocoons followed by different letters in a same day are significantly different (one-way ANOVA; Tukey's test, $p \leq 0.05$ ) in different feed mixtures of bagasse and cattle dung. 


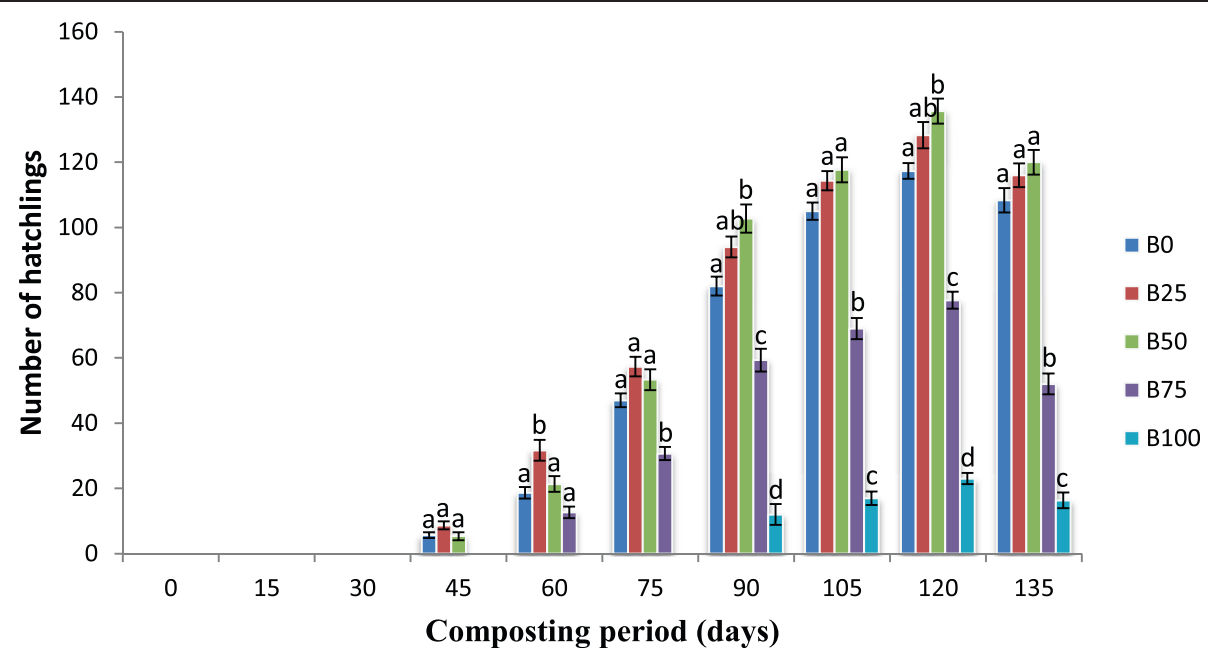

Figure 4 Mean values of number of hatchlings followed by different letters in a same day are significantly different (one-way ANOVA; Tukey's test, $p \leq 0.05$ ) in different feed mixtures of bagasse and cattle dung.

observed in $\mathrm{B}_{50}(135.7 \pm 3.84)$ on 120 th day and minimum in $B_{100}(16.33 \pm 2.40)$ on 135 th day of experiment (Figure 4). Maximum hatchling biomass was observed in $\mathrm{B}_{50}(40.97 \pm 1.33)$ on the 120 th day of experiment and minimum in the $B_{100}(5.36 \pm 0.49)$ feed mixture (Figure 5). Number of hatchlings was lesser in feed mixtures $B_{75}$ and $\mathrm{B}_{100}$ as compared to lower proportions due to low production of cocoons. Increase in hatchling formation during the present study gets supported by Kaur et al. (2010) and Chauhan and Singh (2013).

\section{Physico-chemical characteristics of the mixtures}

The physico-chemical analysis also showed significant difference ( $p<0.01$ ) with varying ratio of waste in different concentrations (Table 3 ). In the present study decrease in $\mathrm{pH}$ was observed. The maximum decrease in $\mathrm{pH}$ was in $\mathrm{B}_{0}(14.73 \%)$ and minimum (6.04\%) in $\mathrm{B}_{75}$ feed mixture. In $\mathrm{B}_{100}$ mixture, however an increase in $\mathrm{pH}$ $(8.85 \%)$ was observed. The decline in $\mathrm{pH}$ during vermicomposting is due to the mineralization of nitrogen and phosphorus compounds and the production of humic

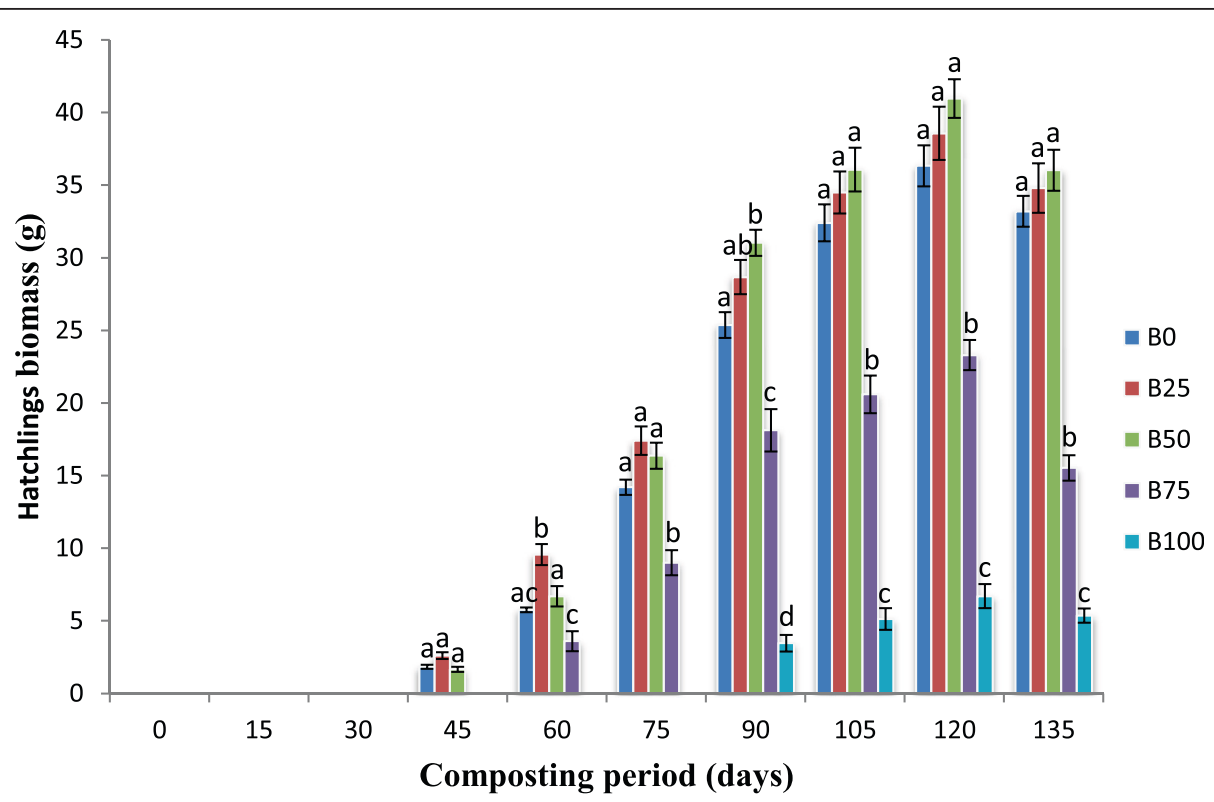

Figure 5 Mean values of hatchlings biomass ( $g$ ) followed by different letters in a same day are significantly different (one-way ANOVA; Tukey's test, $p \leq 0.05$ ) in different feed mixtures of bagasse and cattle dung. 
Table 3 Initial and final nutrient content (mean \pm S.E.) and percent change over initial of different proportions of bagasse and cattle dung

\begin{tabular}{|c|c|c|c|c|c|c|}
\hline \multicolumn{7}{|c|}{ Feed mixtures of bagasse } \\
\hline Nutrient & & $\mathrm{B}_{0}$ & $\mathrm{~B}_{25}$ & $\mathrm{~B}_{50}$ & $\mathrm{~B}_{75}$ & $\mathrm{~B}_{100}$ \\
\hline \multirow[t]{3}{*}{$\mathrm{pH}$} & Initial & $8.35 \pm 0.08$ & $8.25 \pm 0.02$ & $8.13 \pm 0.04$ & $7.77 \pm 0.04$ & $6.55 \pm 0.07$ \\
\hline & Final & $7.12 \pm 0.05^{*}$ & $7.08 \pm 0.08^{* *}$ & $7.41 \pm 0.04^{*}$ & $7.30 \pm 0.04^{*}$ & $7.13 \pm 0.06$ \\
\hline & $\%$ change & -14.73 & -14.18 & -8.85 & -6.04 & 8.85 \\
\hline \multirow[t]{3}{*}{$\mathrm{EC}(\mathrm{mS} / \mathrm{cm})$} & Initial & $4.13 \pm 0.17$ & $3.86 \pm 0.08$ & $3.23 \pm 0.14$ & $1.63 \pm 0.08$ & $1.1 \pm 0.1$ \\
\hline & Final & $5.46 \pm 0.14^{*}$ & $4.60 \pm 0.11^{* *}$ & $4.90 \pm 0.11^{* *}$ & $2.96 \pm 0.12^{*}$ & $2.23 \pm 0.12^{*}$ \\
\hline & $\%$ change & 32.20 & 19.17 & 51.70 & 81.59 & 102.72 \\
\hline \multirow[t]{3}{*}{$\mathrm{TKN}^{\mathrm{a}}$} & Initial & $1.34 \pm 0.01$ & $0.83 \pm 0.02$ & $0.69 \pm 0.05$ & $0.43 \pm 0.01$ & $0.26 \pm 0.01$ \\
\hline & Final & $2.0 \pm 0.03^{* *}$ & $1.77 \pm 0.06^{* *}$ & $1.67 \pm 0.04^{* *}$ & $1.06 \pm 0.03^{* *}$ & $0.86 \pm 0.04^{* *}$ \\
\hline & $\%$ change & 49.25 & 113.25 & 142.02 & 146.51 & 230.76 \\
\hline \multirow[t]{3}{*}{ TOC $^{\mathbf{a}}$} & Initial & $46.28 \pm 0.52$ & $49.92 \pm 0.07$ & $50.30 \pm 0.10$ & $54.25 \pm 0.36$ & $55.53 \pm 0.27$ \\
\hline & Final & $33.79 \pm 0.36^{* *}$ & $32.25 \pm 0.65^{* *}$ & $32.44 \pm 0.56^{* *}$ & $44.51 \pm 0.27^{* *}$ & $49.53 \pm 0.35^{*}$ \\
\hline & $\%$ change & -26.98 & -35.39 & -35.50 & -17.95 & -10.80 \\
\hline \multirow[t]{3}{*}{$\mathrm{C} / \mathrm{N}$ ratio } & Initial & $34.53 \pm 0.26$ & $60.14 \pm 2.39$ & $72.89 \pm 5.52$ & $126.16 \pm 4.05$ & $213.57 \pm 10.6$ \\
\hline & Final & $16.89 \pm 0.43^{* *}$ & $18.22 \pm 0.78^{* *}$ & $19.42 \pm 0.62^{*}$ & $41.99 \pm 1.28^{* *}$ & $57.59 \pm 2.86^{* *}$ \\
\hline & $\%$ change & -51.08 & -69.70 & -73.35 & -66.71 & -73.03 \\
\hline \multirow[t]{3}{*}{$\mathrm{TAP}^{\mathrm{a}}$} & Initial & $0.59 \pm 0.06$ & $0.48 \pm 0.03$ & $0.36 \pm 0.03$ & $0.28 \pm 0.04$ & $0.20 \pm 0.05$ \\
\hline & Final & $1.08 \pm 0.05^{* *}$ & $0.71 \pm 0.05$ & $0.68 \pm 0.04^{* *}$ & $0.40 \pm 0.03$ & $0.30 \pm 0.03$ \\
\hline & $\%$ change & 83.05 & 47.91 & 88.88 & 42.85 & 50.0 \\
\hline \multirow[t]{3}{*}{$\mathrm{TK}^{\mathrm{a}}$} & Initial & $2.23 \pm 0.04$ & $2.38 \pm 0.03$ & $2.48 \pm 0.07$ & $2.85 \pm 0.02$ & $3.19 \pm 0.04$ \\
\hline & Final & $1.96 \pm 0.06$ & $2.47 \pm 0.04$ & $2.78 \pm 0.04$ & $2.98 \pm 0.04^{*}$ & $3.26 \pm 0.06$ \\
\hline & $\%$ change & -12.10 & 3.78 & 12.09 & 1.40 & 2.19 \\
\hline \multirow[t]{3}{*}{$\mathrm{TNa}^{\mathrm{a}}$} & Initial & $8.09 \pm 0.28$ & $5.84 \pm 0.15$ & $5.09 \pm 0.21$ & $2.30 \pm 0.09$ & $1.08 \pm 0.10$ \\
\hline & Final & $13.42 \pm 0.21^{* *}$ & $6.98 \pm 0.27^{*}$ & $7.75 \pm 0.13^{*}$ & $3.88 \pm 0.07^{* *}$ & $2.53 \pm 0.14^{*}$ \\
\hline & $\%$ change & 65.88 & 19.52 & 52.25 & 68.69 & 134.25 \\
\hline \multirow[t]{3}{*}{$\mathrm{Zn}^{\mathrm{b}}$} & Initial & $63.52 \pm 1.62$ & $45.63 \pm 0.55$ & $34.8 \pm 1.42$ & $32.68 \pm 0.59$ & $21.54 \pm 0.24$ \\
\hline & Final & $120.6 \pm 1.28^{* *}$ & $130.2 \pm 3.31^{* *}$ & $115.5 \pm 3.06^{* *}$ & $84.09 \pm 6.19^{*}$ & $60.63 \pm 3.13^{* *}$ \\
\hline & $\%$ change & 89.86 & 185.33 & 231.89 & 157.31 & 181.47 \\
\hline \multirow[t]{3}{*}{$\mathrm{Cu}^{\mathrm{b}}$} & Initial & $55.57 \pm 3.73$ & $37.47 \pm 1.31$ & $32.17 \pm 1.45$ & $25.93 \pm 1.59$ & $18.6 \pm 1.41$ \\
\hline & Final & $41.33 \pm 0.92^{*}$ & $29.57 \pm 1.07$ & $25.4 \pm 2.17$ & $21.6 \pm 1.41$ & $15.47 \pm 1.32$ \\
\hline & $\%$ change & -25.62 & -21.08 & -21.04 & -16.69 & -16.82 \\
\hline \multirow[t]{3}{*}{$\mathrm{Cr}^{\mathrm{b}}$} & Initial & $56.77 \pm 4.28$ & $41.47 \pm 1.45$ & $18.5 \pm 1.07$ & $13.1 \pm 1.38$ & $26.03 \pm 2.64$ \\
\hline & Final & $21.07 \pm 1.33^{* *}$ & $26.83 \pm 1.29^{* *}$ & $15.43 \pm 0.95$ & $11.97 \pm 0.61$ & $22.77 \pm 1.16$ \\
\hline & $\%$ change & -62.88 & -35.30 & -16.59 & -8.62 & -12.52 \\
\hline \multirow[t]{3}{*}{$\mathrm{Fe}^{\mathrm{b}}$} & Initial & $1483 \pm 6.44$ & $760.1 \pm 10.98$ & $698.8 \pm 6.80$ & $334 \pm 6.15$ & $249.5 \pm 7.67$ \\
\hline & Final & $899 \pm 11.15^{* *}$ & $998.9 \pm 11.94^{* *}$ & $1030 \pm 14.44^{* *}$ & $542.5 \pm 6.06^{* *}$ & $459.1 \pm 7.28^{* *}$ \\
\hline & $\%$ change & -39.37 & 31.41 & 47.39 & 62.42 & 84.0 \\
\hline \multirow[t]{3}{*}{$\mathrm{Mn}^{\mathrm{b}}$} & Initial & $83.09 \pm 0.38$ & $54.13 \pm 0.71$ & $45.34 \pm 2.98$ & $24.6 \pm 2.14$ & $16.79 \pm 1.72$ \\
\hline & Final & $181.4 \pm 1.44^{* *}$ & $81.87 \pm 3.67^{*}$ & $66.7 \pm 1.94^{*}$ & $35.1 \pm 2.80$ & $20.67 \pm 2.34$ \\
\hline & $\%$ change & 118.31 & 51.24 & 47.11 & 42.68 & 23.10 \\
\hline
\end{tabular}


and fulvic acids (Ndegwa and Thompson 2000). The decrease in $\mathrm{pH}$ by the earthworm in the feed mixtures $\left(\mathrm{B}_{0}, \mathrm{~B}_{25}, \mathrm{~B}_{50}\right)$ may be due to the earthworm related gut microorganisms responsible for the production of organic acids. Increase in EC was significantly different $(\mathrm{p}<0.01)$. The maximum increase in $\mathrm{EC}$ was in $\mathrm{B}_{100}(102.02 \%)$ and least in $B_{25}$ (19.17\%). The increase in $E C$ for the mixtures of bagasse was $B_{100}>B_{75}>B_{50}>B_{0}>B_{25}$. EC was increased in all the concentrations of bagasse. Karmegam and Daniel (2009) also reported an increase in EC during vermicomposting and is due to the increase in the soluble salt level resulting from the mineralization action of worms and microbes present in the gut of earthworms and those in the organic substance. Decreased in organic carbon in the feed ratios seems to be responsible for the increase in EC of the mixtures. Increase in Total Kjeldhal Nitrogen (TKN) was increased significantly in the products of bagasse $(\mathrm{p}<0.01)$. The maximum increase in TKN was in $\mathrm{B}_{100}(230.76 \%)$ and minimum $(49.25 \%)$ in $\mathrm{B}_{0}$ mixture. Per cent increase in nitrogen of bagasse was in the order of $B_{100}>B_{75}>B_{50}>B_{25}>B_{0}$. In the present study, TKN increased from initial in all the mixtures of bagasse. Cynthia and Rajeshkumar (2012) also reported an increase in TKN of sugar mill effluent and is due to the decomposition of waste by worms to accelerate the nitrogen mineralization process. Earthworm enriches the nitrogen content of vermicompost through decaying tissues of dead earthworms and microbial mediated nitrogen transformation in vermicomposting systems results in further increase of nitrogen (Suthar 2007). TOC of bagasse was decreased significantly from initial in all the feed ratios $(\mathrm{p}<0.01)$. The maximum percentage decrease was in $\mathrm{B}_{50}$ $(35.50 \%)$ and least in $B_{100}$ mixture (10.80\%). The trend of decline in TOC of bagasse was in the order of $B_{50}>B_{25}>$ $B_{0}>B_{75}>B_{100}$. The ingested feed mixtures would be break down and homogenized by E. fetida through muscular activity leading to an increase in surface area for microbial action leading to the decline of TOC content (Suthar and Singh 2008). Prakash and Karmegam (2010) and Bhat et al. (2014) have also observed decrease in TOC during vermicomposting of sugar mill sludge. $\mathrm{C}: \mathrm{N}$ ratio was found to decrease significantly in all the feed ratios of bagasse $(\mathrm{p}<0.01)$. Maximum decrease in $\mathrm{C}: \mathrm{N}$ ratio was observed in $B_{50}$ mixture (73.35\%), whereas, it was minimum in $B_{0}$ mixture (51.08\%). Per cent decline in $C: N$ ratio of bagasse was in the order of $B_{50}>B_{100}>B_{25}>B_{75}>B_{0}$. The $\mathrm{C}: \mathrm{N}$ ratio shows the waste stabilization and mineralization during the process of vermicomposting. Decline in C:N ratio was due to higher loss of carbon through microbial respiration in the form of $\mathrm{CO}_{2}$ along with an increase in nitrogen and stabilization of waste by the action of worms (Hait and Tare 2011; Vig et al. 2011). Similar results were also observed by Bhat et al. (2013, 2014). TAP was increased significantly in all the feed ratios of bagasse
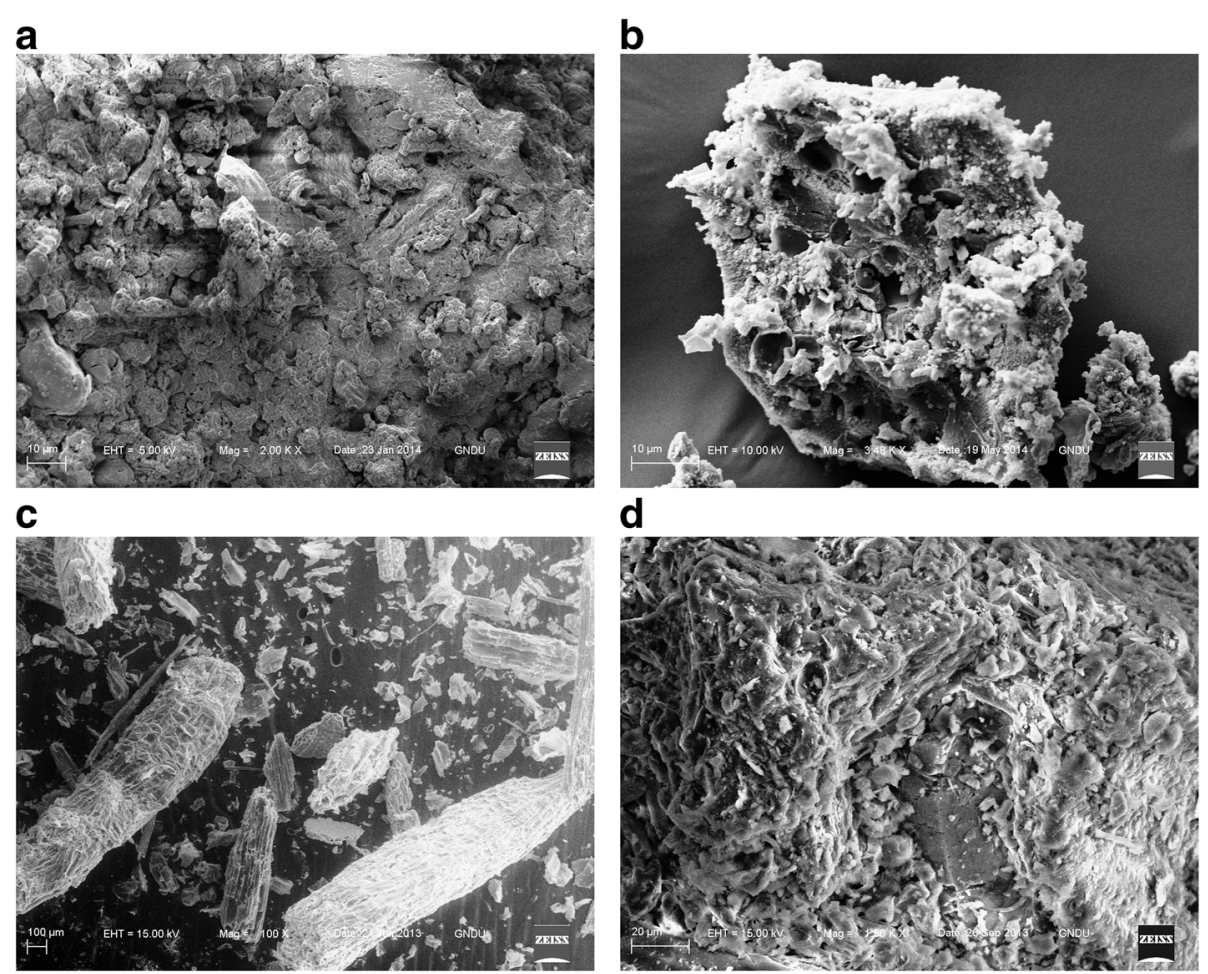

Figure 6 Scanning Electron Microscopy. a) Pre-vermicomposted cattle dung. b) Post-vermicomposted cattle dung. c) Pre-vermicomposted bagasse. d) Post-vermicomposted bagasse. 
( $\mathrm{p}<0.01)$. Per cent increase over initial was maximum in $\mathrm{B}_{50}$ mixture $(88.88 \%)$, whereas, it was minimum in $\mathrm{B}_{75}$ mixture (42.85\%). Per cent increase in TAP of bagasse was in the order of $B_{50}>B_{0}>B_{100}>B_{25}>B_{75}$. The increased phosphorus content in vermicompost clearly indicates earthworm mediated phosphorus mineralization (Suthar 2009). Bayon and Binet (2006), observed that an increase in rise of phosphate content of vermicompost was due to presence of alkaline phosphates in the worm casts. TK increased significantly $(\mathrm{p}<0.01)$, except for $\mathrm{B}_{0}$. The increase was maximum in $\mathrm{B}_{50}$ mixture (12.09\%), and minimum in $B_{75}$ mixture $(1.40 \%)$. Increase in the TK of bagasse was in the order of $B_{50}>B_{25}>B_{100}>B_{75}$ mixtures. Variation in TK concentration among the mixtures has been related to differences in the chemical nature of the initial waste. Increase in TK in bagasse correlates with findings of Adi and Noor (2009) that the solubilization of insoluble potassium is due to the formation of acid during waste decomposition by microbes. Suthar (2008) and Yadav et al. (2010) also observed that vermicomposting of wastes significantly increased the potassium concentration. $\mathrm{TNa}$ was significantly increased $(\mathrm{p}<0.01)$ in the final product of Vermicomposting. Per cent increase over initial was maximum in $\mathrm{B}_{100}$ mixture (134.25\%), and minimum in $\mathrm{B}_{25}$ mixture (19.52\%). The increase in $\mathrm{TNa}$ of the feed mixtures was in the order of $B_{100}>B_{75}>B_{0}>B_{50}>B_{25}$. Increased in $\mathrm{TNa}$ in the present study gets supported by Singh et al. (2010, 2014) and Vig et al. (2011). There was a significant decrease $(\mathrm{p}<0.05)$ in heavy metals over initial except $\mathrm{Zn}, \mathrm{Fe}$ and $\mathrm{Mn}$. Maximum decline of heavy metals was $25.62 \%$ and $16.69 \%$ for $\mathrm{Cu}, 62.88 \%$ and $8.62 \%$ for $\mathrm{Cr}$. $\mathrm{Zn}, \mathrm{Fe}$ and $\mathrm{Mn}$ increased significantly in all the feed ratios of bagasse. Maximum increase was $185.33 \%$ for $\mathrm{Zn}, 84.0 \%$ for $\mathrm{Fe}, 51.24 \%$ for $\mathrm{Mn}$. Heavy metals decreased from initial except some elements. Heavy metal reduction accompany with an increase in the weight of worms. Body tissues of earthworms especially chloragocytes and the intestinal microflora have the capacity to detoxity most of the heavy metals and in the present study reduction may be due to the accumulation of these heavy metals by the body tissues of worms. Metabolic conversion of highly toxic forms of heavy metals to nontoxic form has been observed in $E$. fetida (Arillo and Melodia 1991; Fischer and Koszorus 1992).

\section{Scanning electron microscopy}

SEM was applied to characterize the pre and postvermicomposted sample of $100 \%$ cattle dung (Figure 6a, b) and pre and post-vermicomposted bagasse (Figure $6 \mathrm{c}, \mathrm{d}$ ) to recognize the changes in texture. In the prevermicomposted samples the aggregates of biomass were arranged into cellulose fibres and the protein matrix was strongly bound. However, in the postvermicomposted samples the protein and lignin was disaggregated by earthworms. Earthworms break the waste in the gut that contains various microbes which helps in progressive degradation. The post-vermicomposted mixtures confirmed the presence of greater numbers of surface irregularities, which indicated that the vermicomposting approach resulted in good vermicompost manure with high porosity and nutrient availability.

\section{Conclusion}

Vermicomposting of bagasse i.e waste of the sugar industry was carried out using earthworm E. fetida. Nutrients like TKN, EC, TAP, TNa increased from initial whereas there was decrease in TOC, $\mathrm{pH}, \mathrm{C}: \mathrm{N}$ ratio, and heavy metals. The best growth and reproduction of $E$. fetida were observed in 50:50 $\left(\mathrm{B}_{50}\right)$ mixture. However, greater concentrations of bagasse waste significantly affected the growth and reproduction of E. fetida. SEM results also validate the maturity of compost. Vermicomposting could be introduced as efficient technology to convert bagasse waste into nutrient rice manure.

\section{Competing interests}

The authors declare that they have no competing interests.

\section{Authors' contributions}

SAB: carried out vermicomposting of waste, chemical analysis, SEM and drafted the manuscript. APV: Provided resources, helped in designing, and preparing the draft of manuscript. JS: participated in chemical analysis and helped in preparing the draft of manuscript. All authors read and approved final manuscript.

\section{Acknowledgement}

Sartaj Ahmad Bhat is thankful to the UGC, New Delhi for the financial assistance in the form of UGC-BSR Fellowship.

\section{Author details}

${ }^{1}$ Department of Botanical and Environmental Science, Guru Nanak Dev University, Amritsar, India. '2Department of Zoology, Khalsa College Amritsar, Punjab, India.

Received: 21 November 2014 Accepted: 29 December 2014

Published online: 13 January 2015

\section{References}

Adi A, Noor ZM (2009) Waste recycling, utilization of coffee grounds and Kitchen waste in vermicomposting. Bioresour Technol 100:1027-1030

AOAC (2000) In: Horwitz W (ed) Official Methods of Analysis of AOAC International. 17th ed. Gaitheresburg, Maryland

Arillo A, Melodia F (1991) Reducation of hexavalent chromium by the earthworm E. fetida (Savigny). Ecotoxicol Environ Saf 57:391-394

Bayon LRC, Binet F (2006) Earthworm changes the distribution and availability of phosphorous in organic substrates. Soil Biol Biochem 38:235-246

Bhat SA, Singh J, Vig AP (2013) Vermiremediation of dyeing sludge from textile mill with the help of exotic earthworm Eisenia fetida Savigny. Envi Sci Pollut Res 20:5975-5982

Bhat SA, Singh J, Vig AP (2014) Genotoxic Assessment and Optimization of Pressmud with the help of Exotic Earthworm Eisenia fetida. Environ Sci Pollut Res 21:8112-8123

Chauhan HK, Singh K (2012) Effect of binary combinations of buffalo, cow and goat dung with different agro wastes on reproduction and development of earthworm Eisenia fetida (Hapolotoxida: Lumbricidae). World J Zool 7:23-29

Chauhan HK, Singh K (2013) Effect of tertiary combinations of animal dung with agrowastes on the growth and development of earthworm Eisenia fetida during organic waste management. Int J Rec Org Waste Agri 2:11 
Cynthia JM, Rajeshkumar KT (2012) A study on sustainable utility of sugar mill effulent to vermicompost. Adv Appl Sci Res 3:1092-1097

Ezhumalai S, Thangavelu V (2010) Kinetic and optimization studies on the bioconversion of lignocellulosic material into ethanol. Bioresources 5:1879-1894

Fayolle LH, Michaud DC, Stawiecki J (1997) Influence of temperature and food source on the life cycle of the earthworm Dendrobaena veneta (Oligochaeta). Soil Biol Biochem 29:747-750

Fischer E, Koszorus L (1992) Sublethal, accumulation capacities and elimination rates of $\mathrm{As}, \mathrm{Hg}$ and $\mathrm{Se}$ in the manure worms Eisenia fetida. Pedobiologia 36:172-178

Gajalakshmi S, Ramasamy EV, Abbasi SA (2005) Composting-vermicomposting of leaf litter ensuing from the trees of mango (Mangifera indica). Bioresour Technol 96:1057-1061

Hait S, Tare V (2011) Vermistabilization of primary sewage sludge. Bioresour Technol 102:2812-2820

John MK (1970) Colorimetric determination of phosphorus in soil and plant material with ascorbic acid. Soil Sci 109:214-220

Karmegam N, Daniel T (2009) Investigating efficiency of Lampito mauritii (Kinberg) and Perionyx ceylanensis Michaelsen for vermicomposting of different types of organic substrates. Environmentalist 29:287-300

Kaur A, Singh J, Vig AP, Dhaliwal SS, Rup PJ (2010) Cocomposting with and without Eisenia fetida for conversion of toxic paper mill sludge into soil conditioner. Bioresour Technol 101:8192-8198

Khwairakpam M, Bhargava R (2009) Vermitechnology for sewage sludge recycling. J Hazard Mater 161:948-954

Ndegwa PM, Thompson SA (2000) Effects of stocking density and feeding rate on vermicomposting of biosolids. Bioresour Technol 71:5-12

Nelson DW, Sommers LE (1996) Total carbon and organic carbon and organic matter. In: Page AL, Miller RH, Keeney DR (ed) Method of Soil Analysis. American Society of Agronomy, Madison, Wilcosin, pp 539-579

Pessoa JA, de Manchilha IM, Sato S (1997) Evaluation of sugar cane hemicellulose hydrolyzate for cultivation of yeasts and filamentous fungi. J Indust Microbiol Biotechnol 18:360-363

Prakash M, Karmegam N (2010) Vermistabilization of pressmud using Perionyx ceylanensis Mich. Bioresour Technol 101:8464-8468

Pramanik P, Chung YR (2011) Changes in fungal population of fly ash and vinasse mixture during vermicomposting by Eudrilus eugeniae and Eisenia fetida Documentation of cellulose isozymes in vermicompost. Waste Manage 31:1169-1175

Rao PJM (2005) Comparative performance of cane sugar industry in seven countries. Cooperative Sugar 37:49-52

Rathinamala J, Jayashree S, Lakshmanaperumalsamy P (2008) Potential utilization of domestic wastes as a suitable experimental diet to enhance the biomass of Eudrilus eugeniae in various seasons. Eco Env Cons 14:43-50

Sangwan P, Kaushik CP, Garg VK (2008) Feasibility of utilization of horse dung spiked filter cake in vermicomposters using exotic earthworm Eisenia foetida. Bioresour Technol 99:2442-2448

Singh J, Kaur A, Vig AP, Rup PJ (2010) Role of Eisenia fetida in rapid recycling of nutrients from bio sludge of beverage industry. Ecotoxicol Environ Saf 73:430-435

Singh J, Kaur A, Vig AP (2014) Bioremediation of Distillery sludge into soil-enriching material through vermicomposting with the help of Eisenia fetida. Appl Biochem Biotechnol. doi:10.1007/s12010-014-1116-7

Suthar S (2007) Vermicomposting potential of perionyx sansibaricus (Perrier) in different waste materials. Bioresour Technol 98:1231-1237

Suthar S (2008) Bioconversion of post-harvest residues and cattle shed manure into value added products using earthworm Eudrilus eugeniae. Ecol Eng $32: 206-214$

Suthar S (2009) Growth and fecundity of earthworm, Perionyx excavates and Perionyx sansibaricus in cattle waste solids. Environ Sci Technol 29:78-84

Suthar S, Singh S (2008) Feasibility of vermicomposting in biostabilization of sludge from a distillery industry. Sci Total Environ 394:237-243

Tripathi G, Bhardwaj P (2004) Comparative studies on biomass production, life cycles and composting efficiency of Eisenia foetida (Savigny) and Lampito mauritii (Kinberg). Bioresour Technol 92:275-278
Vig AP, Singh J, Wani SH, Dhaliwal SS (2011) Vermicomposting of tannery sludge mixed with cattle dung into valuable manure using earthworm Eisenia fetida (Savigny). Bioresour Technol 102:7941-7945

Yadav KD, Tare V, Ahammed MM (2010) Vermicomposting of source separated human faeces for nutrient recycling. Waste Manage 30:50-56

Zeyer J, Ranganathan LS, Chandra TS (2004) Pressmud as biofertilizer for improving soil fertility and pulse crop productivity. ISCB - Indo - Swis collaboration in Biotech. A Report Portfolia First Phase (1999-2004)

\section{Submit your manuscript to a SpringerOpen ${ }^{\odot}$ journal and benefit from:}

- Convenient online submission

- Rigorous peer review

- Immediate publication on acceptance

- Open access: articles freely available online

- High visibility within the field

- Retaining the copyright to your article

Submit your next manuscript at $>$ springeropen.com 